\title{
Expectations and the performance of governance functions between a board, management and other stakeholders: the case of Robotdalen
}

\author{
Linda Höglund $^{1}$ (D) Maria Mårtensson ${ }^{2,3}$ • Aswo Safari ${ }^{1}$
}

Published online: 15 February 2018

(C) The Author(s) 2018. This article is an open access publication

\begin{abstract}
Previous research has called for an enhanced understanding of the dynamic and interactional aspects of board work in public sector governance. Using a longitudinal case study of Robotdalen, this paper attempts to meet this call through a processual and qualitative study of board work in public organisations. The aim of the paper is to enhance our understanding of the human side of governance and the interactions between a board, the management in the governed organisation and other stakeholders. We do this by addressing the theoretical concept of an expectations gap. The results demonstrated how funding regimes influence governance functions, structures and practices at the organisational level, and how internal actors such as managers also carry out governance functions. Moreover, the results show how an expectations gap shifts and changes over time. In this way we have contributed a more nuanced theoretical understanding of how the governance function is co-produced and the importance of understanding the expectations gap to further understand the dynamics of public sector board work.
\end{abstract}

Keywords Board-work - Governance functions - Expectations gap $\cdot$ Public sector . Case-study

Linda Höglund

linda.hoglund@mdh.se

Maria Mårtensson

mm@sbs.su.se

Aswo Safari

aswo.safari@mdh.se

1 School of Business, Society and Engineering (EST), Mälardalen University, Box 883, 72123 Västerås, Sweden

2 School of Business and Economics, Linnaeus University, 35195 Växjö, Sweden

3 Stockholm Business School, Stockholm University, 10691 Stockholm, Sweden 


\section{Introduction}

This paper adopts and explores the concept of an expectations gap between a board and a public organisation and the performance of governance functions in relation to other stakeholders. Thus, the aim of the paper is to enhance our understanding of the human side of governance and the interactions between a board, the management in the governed organisation and other stakeholders.

Research on boards in general has received substantial attention in recent decades (Minichilli et al. 2009). Nevertheless, so far research has mainly been concerned with large private sector organisations, which has meant that less research has been conducted on public organisations, even though their importance has been argued for several times (cf. Cornforth 2003, 2004, 2012; Gnan et al. 2013a). There has also been a lack of attention among researchers towards the study of board dynamics and interactions between an organisation and its board (Cornforth 2012). This even though it has been recognised it is crucial to understand dynamic and interactive processes in relation to board work effectiveness and performance (Brown 2005, 2007; Minichilli et al. 2009). Huse (2007) also stated that, in order to understand the human side of governance, it is vital to study the interactions among actors, for example, between a board and the governed organisation.

Research into boards has traditionally focused on board structure with regard to composition, role, and tasks (Huse 2000; Cornforth 2004, 2012) and its relation to organisational performance (Brennan 2006). In trying to synthesise previous literature on board work, Minichilli et al. (2009) conclude there are two main perspectives. The first is a controlling perspective, whereby the board is a tool for principals/ owners/stakeholders to control the organisation. The second is a service perspective, in which the board should assist the organisation in various ways; in other words, it becomes a tool for resource acquisition, strategy development, and contact with the surrounding world. These perspectives can be seen as two extremes that, in practice, need to be balanced (Höglund et al. 2015). As Cornforth (2003, p. 14) put it, "boards face a tension concerning how much attention they should pay to these contrasting roles and how to balance the different demands on them." These tensions often emerge as the board and the governed organisation have different expectations of their roles and tasks (Brennan 2006). Moreover, board members are obligated by different expectations from their own organisation which do not always coincide with those of the governed organisation (Cornforth 2012). Expectations, however, is a research area within board work that is unexploited but has great potential for advancing our understanding of the dynamic and interactional aspects that have been called for in previous research on public sector governance (see e.g. Cornforth 2003, 2004, 2012; Hinna et al. 2010; Gnan et al. 2013a). In line with these thoughts, we address the concept of expectations in relation to board work in the next part of the paper. 


\section{Board work and expectations gap}

To understand the performance of governance functions and expectations, we need to understand the composition and structure of the board. As such, we should take into careful account the understanding of organisational characteristics, the mixture of competences and backgrounds on the board and the need to create a stimulating working style and environment (Minichilli and Hansen 2007). The structure of the board and its composition regarding board task performance, board roles and functions has, however, been categorised in various ways (Huse 2000) and different board tasks have been argued to have value-creating contributions (Johnson et al. 1996; Huse 2005). This is as a result of scholars who have used many different theoretical perspectives in order to understand board work, its function and role e.g. agency theory, stakeholder theory, resource dependency theory, stewardship theory and a democratic perspective (Cornforth 2003).

Agency theory could be seen as dominant and focusing upon the board's role to control managers, with the function of protecting the interest of the owners (cf. Hung 1998; Cornforth 2003; Huse et al. 2008; Gnan et al. 2013b). Similarly, stakeholder theory argues that the role of the board is to control managers and to coordinate stakeholders; thus the function of the board is to protect the interests of stakeholders (cf. Hung 1998; Cornforth 2003; Gnan et al. 2013b). The second most dominant theory is resource dependency, which takes the view of the board's role as working together with top managers to strategically manage the organisation, acting as a link between the organisation and the external environment (Hung 1998; Cornforth 2003; Minichilli et al. 2009). Stewardship theory also focuses on the board's role as working together with management to add value to the organisation, but with the function of providing service in strategic matters (cf. Hung 1998; Cornforth 2003). Last, we have the democratic perspective where the role of the board is to protect democracy - 'one member-one vote'-with the function of negotiating a broad compromise among different views and groups in the organisation (Cornforth 2003).

So far, there are few research papers that address expectations in governance and board work, and if we turn to public sector literature there are even fewer. However, when doing so, it emerges that the role and function of the board becomes an important aspect to consider (Brennan 2006). Thus, those who have studied board work and expectations tend to conclude that there are tensions in relation to board work and the governed organisation i.e. regarding what to expect from both parties (Cornforth 2003, 2012). Drawing upon auditing literature, Brennan (2006) suggests that the expectations gap is based on two elements: a reasonableness gap and a performance gap. These arguments are in turn inspired by Porter (1993), who did an empirical study where he defined the expectations gap as the gap between society's expectations of auditors and auditors' performance, as perceived by society. In this way, he introduced the ideas of a reasonableness gap and a performance gap. The reasonableness gap refers to the gap between what society expects auditors to achieve and what the auditors can reasonably be expected to accomplish. On the 
other hand, the performance gap refers to the gap between what society can reasonably expect auditors to accomplish and what auditors are perceived to achieve.

Brennan (2006, p. 578) introduces the reasonableness gap and the performance gap as a way to understand the expectations gap in board work and in performing governance functions, and in so doing defines a reasonableness gap as 'a gap between what is expected and what can reasonably be expected to accomplish' and a performance gap as: 'a gap between what can reasonably be expected and perceived actual achievements.' She also states that a lack of clarity about the role and tasks of a board and its mission can lead to an expectations gap, which might have consequences for organisational performance. Therefore, it is important that board members are well-apprised (McAdam and Gies 1985), which affects the communication of the board's role, tasks and mission (Huse and Rindova 2001; Brennan 2006).

In line with Michaud (2014, p. 98), we argue that we need a deeper insight into 'what boards do' over time, and how practices of governance can change and evolve when different stakeholders interact. This is similar to Cornforth's (2012) call for more processual and qualitative studies of governance in a context of public sector board work. In line with these thoughts, we draw upon Cepiku (2013, p. 20) and adopt a micro-perspective of governance-what she defines as 'outward-oriented public management, where the strategic steering role includes problem-solving and stakeholder involvement capabilities'. In so doing, we also draw on Cornforth's (2012) broader conceptualisation of public governance, which recognises that both internal and external actors contribute to the performance of governance functions. This means that we focus on the process of how governance practices emerge and how an expectations gap can shift over time between a board and its management in producing different governance functions. This leads us to the research question: How are board and management expectations constructed over time in relation to governing functions in a public sector context?

\section{Method}

\subsection{Case study}

A case study approach is particularly suitable in a context of longitudinal research that is trying to unravel the underlying dynamics of phenomena that play out over time insofar as it has the potential to provide details of how these dynamic processes actually play out (Höglund et al. 2015; Höglund and Linton 2018). Robotdalen is a small public organisation in Sweden. We followed the case of Robotdalen in real time between 2009 and 2016, and retrospectively from its start in 2003, to enhance our understanding of the human side of governance and how management, board members, financiers (including representatives from both public and private sector organisations), and the hosting university, all contributed to the performance of governance functions. Moreover, we have tried to understand the performance of governance functions in relation to expectations from the board towards Robotdalen and vice versa. In other words, in this paper we focus on how the performance of governance functions evolves and changes over time in relation to what expectations 
the board and management have, expectations most likely influenced by different stakeholders. Since organisational governance structures and practices do evolve and change over time to meet new demands and circumstances (Cornforth 2012), it would be reasonable to assume that the expectations of the board towards the governed organisation's performance and vice versa would also change. In this context, the study of Robotdalen ought to provide important insights.

However, it is important to address the fact that the case study approach is used in many different situations (Ragin and Becker 1992) and case study researchers tend to focus on different characteristics. The most usual approaches are, nevertheless, to focus on the case study as a method per se and its techniques (e.g. Glaser and Strauss 1967; Yin 1994; Eisenhardt 1989), or to take a more social constructionist view with a focus on the interpretative aspects, not the methods (e.g. Stake 1995, 1998). In this paper, we draw upon the latter. In accordance with Stake (1995), this study interprets the case, Robotdalen, in order to convey and conceptualise an understanding of the processes of governance and address gaps in existing theory (cf. Siggelkow 2007).

A longitudinal case study involves studying processes of change over time. Hence, the empirical material was generated between 2009 and 2016, and consisted of 37 formal interviews with 25 respondents, several informal meetings, participant observations and document studies. Open interviews were conducted with all board members, regional representatives, representatives of financing bodies, the hosting organisation and the management team. Table 1 is a summary of the formal interviews, which lasted for 60-120 min and were recorded and transcribed verbatim. The interviews were characterised by being more of a conversation between the interviewer and the interviewee where the interviewee talked about the performance of Robotdalen, their experiences to work with or at Robotdalen, what expectations they have or had of Robotdalen and the overall status of Robotdalen as they perceived it. The interviews are complemented with documents, such as press releases, extracts of e-mail conversations, PowerPoint presentations, agendas for meetings and more general news about Robotdalen.

Most previous research on board work has so far been made on large privatesector organisations and based mainly on large surveys (Yar Hamidi and Gabrielsson 2012) with the CEO and/or the chairman focusing on causal effects of behaviour (Cornforth 2012). In this context, Cornforth (2012) calls for qualitative studies

Table 1 A summary of interviewed respondents

\begin{tabular}{lll}
\hline & $2009-2012$ & $2013-2016$ \\
\hline Interviews in total & 18 & 19 \\
Robotdalen management & 2 respondents (8 occasions) & 2 respondents (6 occasions) \\
Robotdalen employees & 4 respondents & \\
University & 2 respondents & 4 respondents (5 occasions) \\
Government & 2 respondents & 2 respondents \\
Industry & 2 respondents & 5 respondents (6 occasions) \\
\hline
\end{tabular}


that focus on examining the process of interaction between public organisations and boards by also involving a greater number of stakeholders. This paper is an attempt to meet this call. Thus, the case of Robotdalen is an excellent case to give some insights into how the performance of governance functions evolves over time in interaction between a board, the management team and other stakeholders. Robotdalen is a collaboration project among a number of organisations, including universities, global enterprises, SMEs, municipalities, and regional and local governments. The project's overall aim is to enable new robot innovations within industry, service, and health care. They are financed by, among others, the Swedish Governmental Agency for Innovation Systems (VINNOVA), the EU Regional Development Fund, municipalities, counties and industry representatives. Lastly, Robotdalen is hosted by a university and as such they have to act in accordance with the laws and directions of their host, which makes the university a key stakeholder to consider. In other words, there are plenty of different stakeholders involved in Robotdalen and in the work of producing governance functions (Höglund et al. 2015).

\subsection{Analysis of the empirical material}

To answer the stated research question of how board and management expectations are constructed over time in relation to governing functions in a public sector context, we first need to analyse what the expectations are from the board and the governed organisation. This is important, as previous literature has shown that an expectations gap can have an effect on the performance of the organisation and governance functions. We present our case analysis of Robotdalen using Brennan's (2006) conceptualisation of the expectations gap. Therefore, the case analysis in the next section is based on the following questions:

- What expectations does the management of Robotdalen have of the board?

- Is it reasonable for the board to accomplish what the management of Robotdalen expects of it?

- How does the management of Robotdalen perceive the performance of the board?

- What expectations does the board have of the management of Robotdalen?

- Is it reasonable for the management of Robotdalen to accomplish what the board expects of it?

- How does the board perceive the performance of Robotdalen and its management?

As Van de Ven (2007) argues, process studies seek narrative understandings of how change happens in terms of the central actors involved in the change process, how they make it happen, to which extent change occurs and the sequence of events that lead to change. By going through the documents, transcriptions and listening to the recorded interviews we constructed a cohesive story in relation to the six stated questions based on the framework of Brennan. By presenting the empirical material based on these empirical questions, we can analyse whether there is an expectations 
gap and, if so, whether it can be regarded as a reasonableness gap or a performance gap.

Taking an interpretative approach to our case study means that we as researchers have interpreted our case based on the theoretical framework of an expectations gap and previous research on board work, as well as the statements from the interviewees. Interpretative studies have been criticised for being subjective, so it is important to show a high degree of transparency regarding our interpretations. We tried to do this by presenting extensive quotations in the empirical analysis and highlighting what theoretical support we base our arguments on. This gives the reader the opportunity to make their own assessment as to whether or not our claims are valid.

In the first part of the analysis we started to code the data by categorising the empirical material into the six addressed questions. The coding stage could be considered as precursor to the analysis, and involved going through a large amount of text searching for instances of reported expectations gap, and it can be described as an analytic initial preparation (cf. Wiggins and Potter 2008). This yielded our first indications of what possible expectations gap there could be between the management and its board. Thereafter, with the help of the theoretical framework we started to interpret the categorised text in relation to the theory and started to construct a cohesive story of the processes of interaction that had occurred between the management and the board (cf. Van de Ven 2007).

Moreover, as stated we take a micro-perspective of governance in this paper. In trying to understand the human side of governance, we take on a view that governance functions involve structures, systems, and processes concerned with ensuring the overall direction, control, and accountability of an organisation (Verschuere and Beddeleem 2013) and that includes other stakeholders in performing governance functions. For example, as in the case of Robotdalen the financiers and the hosting University have shown to be of importance when performing governance functions as they could be coproduced (Höglund et al. 2015). With this in mind, it is not unreasonable to think that these stakeholders could also have an effect on the expectations of the board and the governed organisation (cf. Brennan 2006). This we will approach more thoroughly in the discussion of the results.

\section{A case analysis of expectations}

As a short introduction to Robotdalen, we can state that it started in 2003 as a collaboration project between two regional universities, a number of global enterprises such as ABB, Volvo, and Atlas Copco, a number of SMEs, several municipalities, regional and local governments, and hospitals. Robotdalen can be positioned as a small public organisation that is hosted by a regional university in Sweden. It is managed by a general manager and a vice general manager who work full time. Most of the staff at Robotdalen only work part time; see Table 2 for an overview of the number of employees and the annual budget for the years 2007-2016.

The largest financier of Robotdalen is the Swedish Governmental Agency for Innovation Systems (VINNOVA), which has been part of the funding of Robotdalen since it started in 2003. Other supporting financiers are the EU Regional 
Table 2 Annual budget and number of employees

\begin{tabular}{lll}
\hline Year & Annual budget $^{\mathrm{a}}$ & Employees \\
\hline 2007 & $1,740,000$ & 11 \\
2008 & $2,340,000$ & 11 \\
2009 & $3,000,000$ & 15 \\
2010 & $3,300,000$ & 12 \\
2011 & $2,700,000$ & 12 \\
2012 & $2,700,000$ & 12 \\
2013 & $2,500,000$ & 10 \\
2014 & $2,100,000$ & 15 \\
2015 & $1,500,000$ & 14 \\
2016 & No information & 13 \\
\hline
\end{tabular}

${ }^{\mathrm{a}}$ The annual budget has been converted from SEK to EUR and is thus approximate

Development Fund, regional municipalities and counties and industry representatives. Robotdalen is both autonomous in the sense that it is governed by a board of directors consisting mostly of financiers, and dependent insofar as it is subject to the rules and regulations that apply to a Swedish publicly governed university (Höglund et al. 2015; Höglund and Linton 2018). Thus all financial, legal and staff issues are managed and controlled by the university.

To get an overview of how Robotdalen performed from 2007 until 2016, we summarised the reported performance of Robotdalen from the annual reports including the main reported events, see Table 3.

\subsection{What expectations does the management of Robotdalen have of the board?}

In the beginning, Robotdalen's expectations of the board were quite low. It is mainly expressed in line with this statement of one from the management team:

As long as the [the board] act as they are supposed to [...] follow the instructions and don't make your life hard [...] we did not expect anything.

As stated, Robotdalen is hosted by a university and as such it must act in accordance with their laws and regulations. It is the rector of the university who appoints the board of directors, the chairman of the board and makes the formal decision on the role and function of the board. The initial instructions stated the following:

For Robotdalen there will be a board of directors. The board will consist of eight (8) members, including the chairperson. Members are appointed by the principal [of Mälardalen University] after consultation with Robotdalen's currently existing co-founders and partners. The members of the board will be represented as follows: 1 representative from industry, 2 representatives from universities, 3 representatives from the municipality and county administrative board. The chairperson is proposed by the parties from Örebro County. The 


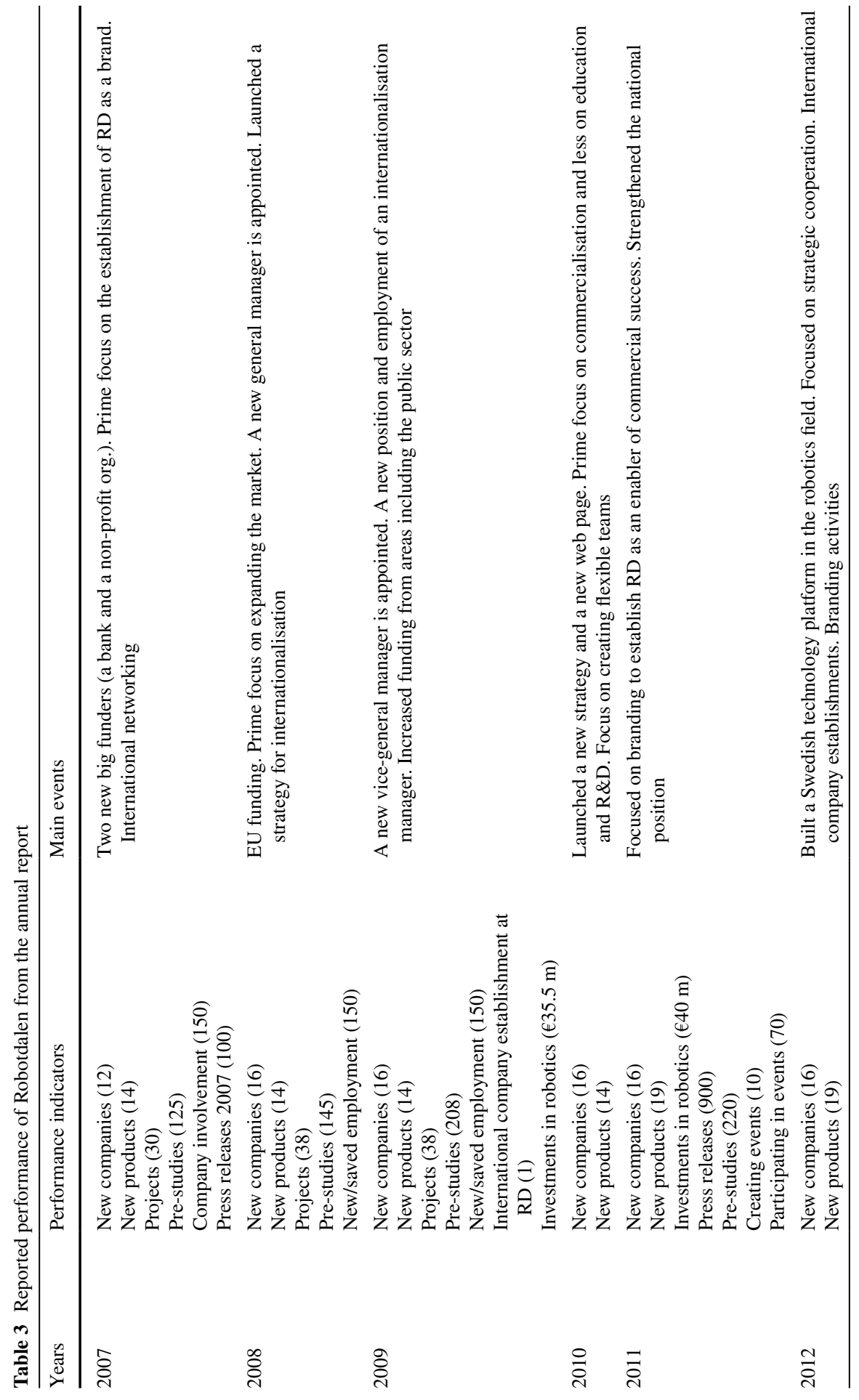




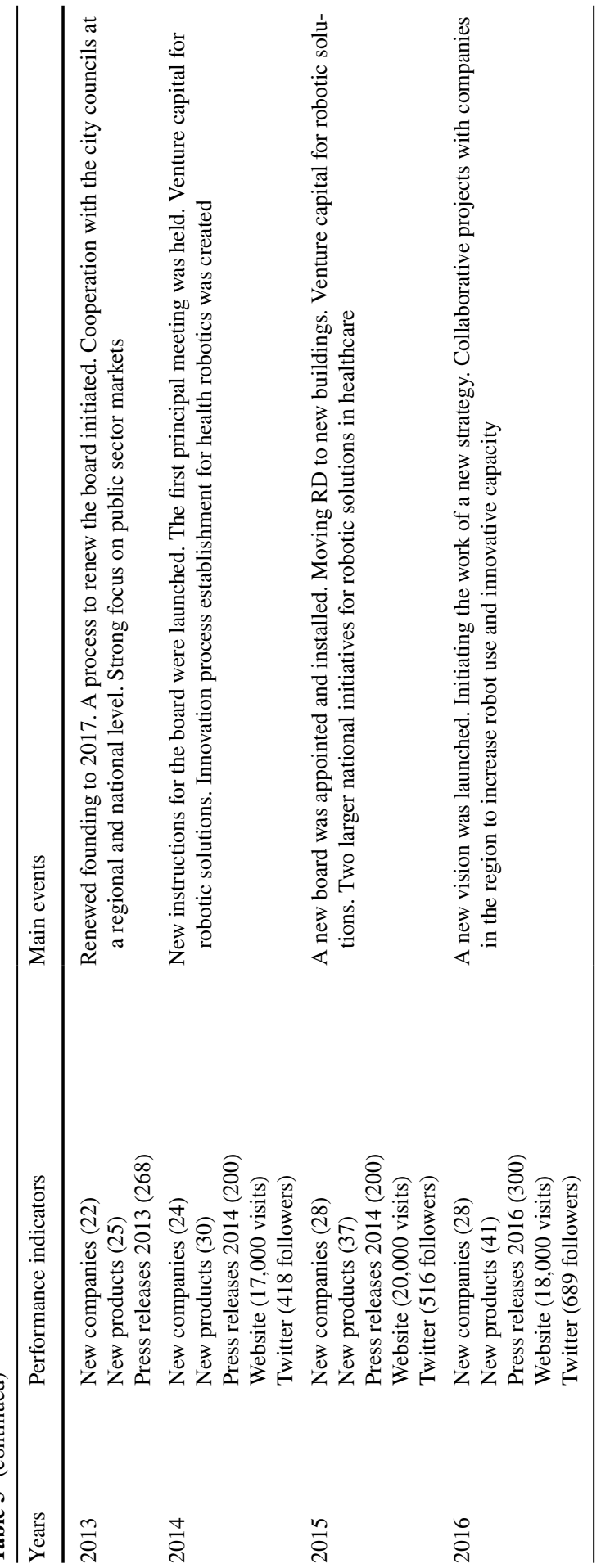


vice-chairperson is appointed by the board. The appointments will strive to achieve equal representation from the three counties.

In line with the instructions, the appointed chairman of the board was a county governor, and the board members were representatives from regional industry, the municipality and from the universities. What Cornforth (2003) would argue is a board composition based on representativeness rather than expertise. Thus, membership is granted according to an equal representation of the three counties. Moreover, based on the instructions, and requirements from several of the financiers to possibly monitor their interests, the financiers were elected onto the board. As financiers, they could also be regarded as the owners of Robotdalen.

However, as Robotdalen matures, the complexity of the organisation and how to manage it increases. For example, the work of finding a strategy that clearly positions Robotdalen amongst other similar actors in the innovation system was important. In this effort, it is possible to state that Robotdalen has continuously worked on finding their strategic niche to operate in since their establishment in 2003. After several revisions of the strategy, they carried out a major renewal of the strategy in 2010. In this new strategy, Robotdalen positioned itself in a unique niche, stating that they compete as an enabler of commercial success. With the updated strategy, they gained a more streamlined and clearer strategic focus. For example, with the new strategy, the business of Robotdalen was divided into three main areas: industrial robotics, field robotics (e.g. autonomous vehicles) and technology for independent life, from previously operating in six areas. They also developed a stronger national and international focus, from previously mainly being a regional actor. They previously also did a lot of work for education.

Moreover, for 10 years, from 2003 to 2013, Robotdalen had received a large part of their funding from VINNOVA. Funding has been renewed until 2019, but will gradually be decreased (starting from 2015) by VINNOVA and needs to be supplemented by funding from other stakeholders, with the aim of becoming self-sufficient. The fact that funding will decrease has been expressed as an important factor for the future strategic direction of Robotdalen and its survival. On several occasions the management team has expressed the need for enhanced involvement from the board regarding support and competence of the board in the strategy work and in finding new financiers. In other words, the management required a governance function of the board where they assist the management team with an expertise and supporting role (cf. Minichilli et al. 2009).

To sum it up, the initial expectations of the board on the part of Robotdalen were that they would follow the instructions. Over time, as Robotdalen changed their strategy, their expectations of the board are also changing as the organisation develops and becomes more complex, but also that the founding decrease that forces Robotdalen to act in a different way that include more interaction with the board. 


\subsection{Is it reasonable for the board to accomplish what the management of Robotdalen expects of it?}

As stated initially, Robotdalen and its management team did not have great expectations of the board other than that it should work in line with the instructions; this could be considered reasonable as the board had agreed to take on the assignment in line with the instructions. Moreover, the management team expected the board to work in the best interest of Robotdalen, which could also be argued as reasonable. However, with time and as Robotdalen evolved and became more complex, Robodalen's requirements of the board and what they expected them to do and contribute to in regard of competence changed. For example, Robotdalen expected that the Board would put more of their time and effort into supporting Robotdalen in their strategy work, which, according to the management team, they didn't do except for a few individual initiatives.

A couple of the board members actively worked with management in supporting them and developing strategies. It could, nevertheless, be argued that this is not part of the instructions to the board and, as such, is not a formalised practice. Therefore, it could also be argued that it is not reasonable to expect the board to take on this role (Brennan 2006). Instead, it can be seen that some of the board members have been flexible enough to act in situations other than those they were accountable for as a board when the management of Robotdalen has needed their support. Some of the board members also interacted with different stakeholders and contributed resources such as network contacts and help in raising funds. This is neither formalised nor a part of the formalised instructions for the board. Consequently, such activities are not a reasonable expectation of Robotdalen as it is not what the board agreed to do. Hence, the board expressed that it had performed in line with the instructions and with what it was accountable for, even though there was a common agreement that the instructions might not be right for where Robotdalen is today.

In sum, the initial expectations of Robotdalen towards the board could be argued as reasonable as they expect the board to follow the formal instructions. With time, however, a reasonableness gap emerged regarding the expectations of Robotdalen, as they require more of the board than they signed up to do; that is, more than the board is accountable for according to the instructions.

\subsection{How do the management of Robotdalen perceive the performance of the board?}

In the majority of the interviews, it was expressed that the board did not perform in line with the expectations of Robotdalen as they were not able to put their own stake and interests aside, i.e. they tended to put their representative organisations before Robotdalen. In other words, the management team at Robotdalen made statements that they perceived that the board did not act in line with the instructions and the stated objectives. The general manager expressed it thus: 
I often must remind the board members that they do not represent their own organisation in the board work and that their role is to represent Robotdalen as a whole.

The empirical material as a whole shows that a lot of time has been devoted to discussions on equal distribution of money among the three counties, which has limited organisational performance. The general manager also expressed the view that:

At a board meeting one of the board members questioned that so much funding goes to a specific region and they finance so little in Robotdalen compared to the region she represented. Then the board member had misunderstood it all and looked at how we run a given project and I had to show her our entire project portfolio and how the money was distributed and the distribution of money was quite even. In other words, over time, it averages out in accordance with some kind of normal distribution principle.

Another concern expressed by both board members and the management team was that the composition of board members based on representativeness of the owners makes the board weaker, that is, not as action-oriented as it could have been if the board composition had been based on competency. Moreover, some of the interviewees expressed the view that if the board was changed, the general manager would probably receive better support in managing Robotdalen.

Several times over the years, the management team came back to the claim that they are the ones that have to do all the work in finding new financiers as well as coming up with new strategies and they would need better support from the board. In 2010, Robotdalen was evaluated by an external actor at the request of VINNOVA, its largest financier (cf. Cooke et al. 2010). One of the conclusions drawn was that the organisation would benefit from a review of the work performed by its board. This was subsequently discussed at several board meetings and in 2013 a workinggroup was formed to investigate the possibility of renewing the board. In 2014 the rector at the hosting university approved new guidelines for the board, upon which a working committee was appointed with the remit of identifying and recommending new board members in accordance with these guidelines. In 2015, a new board was installed and in the spring of that year it had its first meeting.

In sum, Robotdalen perceived the board's performance as poor. Initially, this was mainly because the board has problems in separating their own interests from the interest of Robotdalen. Later on, it was mainly because of the lack of competence and support in strategy work and finding new financiers to compensate for the decreased funding from VINNOVA.

\subsection{What expectations does the board have of the management of Robotdalen?}

The board's initial expectations of Robotdalen were that it would act in accordance with its instructions. Parts of Robotdalen's instruction could be read in the instructions to the board, where it is stated that the board is accountable for making sure that: 
- The overall objectives of Robotdalen are met.

- The work in Robotdalen is conducted in an effective and productive manner.

- Contributions are made to the development of the innovation system.

- An annual plan and a budget based on the action plan is established.

- The work is implemented according to the plan, budget and action plan.

- Decisions are proposed to the head chancellor regarding projects that exceed 50,000 euro.

- There is a general manager at Robotdalen.

- The general manager performs his or her duties in accordance with the instructions.

The instructions to Robotdalen, as well as what the board is accountable for, are permitted by the rector at the hosting university and as such the instructions had to be in line with the rules and governance functions of the university itself. Moreover, parts of the instructions also needed to be constructed upon requirements from Robodalen's largest financier, VINNOVA, i.e. that Robotdalen has to contribute to the innovation system is one of their requirements.

The board's expectation on Robotdalen is also affected by the composition of the board, which was originally based on monitoring aspects of the financiers and representativeness (Höglund et al. 2015). Thus, the initial composition of the board resulted in much of its work being focused on balancing different interests among the board members as they represent different organisations, both private and public, with their own goals and interests in mind. For example, representatives from the universities were mainly interested in research output, and the representatives from the municipality and county administrative boards were interested in how Robotdalen contributes to the innovation system and creates new jobs, while industry was interested in how Robotdalen contributes to growth and profitability in its organisations. Several of the public organisations as well as their main financier, VINNOVA, are also interested in supporting democratic values, such as multicultural and gender issues. In other words, the board's expectations were not only based on the instructions to Robotdalen, or their stated goals; rather, they were based on their own interests and goals as financiers and representatives of the interests of their own organisations.

The board pointed out a concern raised by the management team that it was impossible to meet all the goals and requirements they forced upon the management team and there were discussions on how they would continue to work. It was not, however, until a new general manager was appointed in 2007 that the board and the management team started to move towards an agreement on what Robotdalen was expected to perform. The new general manager introduced new performance measurements, for example, with the purpose of reducing the number of key performance indicators (KPIs) in the growth of new products and new companies. The two quite simple performance measures were expressed as a way to create more transparency and legitimise the organisations' actions towards the board and their other owners. The new performance measurements have so far met the expectations of both the financiers and the board. Even though not all the demands of the financiers have been met (for example, those regarding democratic values and gender and 
multicultural aspects), the results and impacts have been considered important for society and Robotdalen has consequently continued to receive financial support.

In sum, initially the board expected Robotdalen to follow the instructions and meet the requirements of its hosting organisation i.e. the university, but also to meet the different goals of the organisations they represented on the board. Over time, the board's expectations shifted to focus rather on Robotdalen performing in line with the two main KPIs of new products and new companies.

\subsection{Is it reasonable for the management of Robotdalen to accomplish what the board expects of it?}

During the first years, one might question how reasonable it was for the board members to favour their own stake and interests, given that they were involved in board work, and that this situation became part of the expectations of Robotdalen. According to Robotdalen's management team and some of the individual board members, it was not the case, as the expectations of Robotdalen were not fully in line with the instructions or the objectives set for the organisation. Several of the board members, nevertheless, argued that it could be considered reasonable that Robotdalen also performed in line with the expectations of the financiers' requirements (all the board members at the beginning were financiers), even though they stated that they also understood the complexity of taking so many different requirements into account. As the board members expressed sympathy with the management team, some of them argued that it was important that a board member could sort out their own stake and interests from those of the governed organisations. One of the initial board members referred to this by addressing the issue of where the loyalty lies among the board members:

There is much suspicion in this type of organisation where financing is done in collaboration between the private and public sectors. I do not think that this kind of organisation would have worked in the beginning if legitimacy had not been there in terms of board composition. But it is a balancing act. The important point, though, is when people are asked to be part of the board to emphasise that they do not represent their own organisation, but Robotdalen.

In sum, the board expects Robotdalen to follow its instructions and meet the requirements of its parent organisation, as well as the different goals of the board's own organisations. However, the expectations that Robotdalen had could be argued to be unreasonable as they require more of the board then they have signed up for, that is, more than the board is accountable for according to the instructions.

\subsection{How does the board perceive the performance of Robotdalen and its management?}

As several of the board members stated, Robotdalen initially only partly did what was expected of them in terms of performance. Robotdalen did follow the instructions, but there were several shortcomings regarding how they perceived Robotdalen 
had performed in relation to the requirements that have been set by the financiers, but not only those parts of the board but also VINNOVA and the hosting university. One of the initial board members also explained that this perceived lack of performance was very much based on the fact that Robotdalen at the beginning was more or less governed by what he called a "possession operation", thus:

Robotdalen had such strong connections to ABB and the hosting university which makes it a risk of being a possession operation including the rector of the university. The first general manager and these stakeholders dominated Robotdalen too heavily at the beginning to make the organisation (Robotdalen) stand on its own feet.

Another of the initial board members stated that

We, as representatives of the public sector, would of course like to ensure that Robotdalen becomes a growth-enhancing tool for the region. So we all have our agendas, so to speak. I think it's good then that Robotdalen has such a heterogeneous board. It gives you plenty of perspectives and it has been the success of Robotdalen in combination with talented people. The first general manager created much annoyance at the beginning. He was good at the start, so to speak. But he was not good at following rules and creating structure. It was the start that was his strength. When the current general manager came in, it became better in that respect. It's very much about having the right competence and skills for the job.

The previous two quotations are examples of how the board and its members were discontented with the performance and actions taken by the first general manager. The latter quotation also addresses the fact that the first general manager was replaced with a new one. This was due to the board, but also other financiers, perceiving a lack of performance at Robotdalen.

With the new general manager, a new vision and a more niched strategy and goals where developed in 2010. It was put forward that Robotdalen should be an enabler of commercial success. The new strategy also included the two KPIs of new products and companies. This new strategy was approved by the board and has then acted as the frame of reference that the board uses to evaluate how they perceive the performance of Robotdalen. So far, the board has expressed the overall perception that Robotdalen performs very well.

Robotdalen's performance has also been acknowledged by other stakeholders and the organisation is often described as a successful collaborative initiative that has led to several important performance aspects. For example, a report published by OECD (2012, p. 33) drew the following conclusions:

Robotdalen is unique among assistive robotics developers for its integrative approach to robotics research, corporate development for young robotics companies, local economic development and job creation. No other robotics innovation project offers a similar combination of research-driven innovation combined with pragmatic strategic planning in order to build and scale new companies. 
In sum, the board perceived at the beginning that Robotdalen did not perform in line with their expectations and they decided to replace the general manager with a new one. With the new general manager, a new strategy was approved by the board that has worked as a frame of reference for how they perceive Robotdalen's performance. As a result, they have shifted from perceiving Robotdalen as exhibiting poor performance to good performance.

\section{Expectations gap: a discussion of results}

From the analysis of the case, one can state that there has been an expectations gap between the board and the management team since the start of Robotdalen. The results are summarised in Table 4 . At the beginning, the management team and the board members had expectations of each other to follow the instructions. However, neither of the parties perceived that this was done by the other and there was a clear expectations gap based on perceived performance, but also in regard to a reasonableness gap. Let us further elaborate on this.

From the perspective of the management team at Robotdalen, the expectations gap was very much based on a performance gap and a reasonableness gap. The board followed the instructions, but did not put the interests and goals of Robotdalen first as the board members tended to prioritise the stake and interests of their own organisations before Robotdalen. This is something that has been acknowledged as a problem in previous literature (see e.g. Brennan 2006; Cornforth 2012). There was also a reasonableness gap at the beginning. Hence, it is put forward in the empirical material as well as in the theoretical analysis it is reasonable that Robotdalen follow the instructions and the rules of the hosting university, but not that they fulfil the goals of the board members' own interests.

The board, on the other hand, perceived that Robotdalen, and especially the general manager, did not perform in line with their expectations; the board expected Robotdalen to follow its instructions and meet the requirements of its hosting organisation, as well as the different goals of the board's own organisations as they are financiers of Robotdalen. In other words, there is a performance gap. This gap in performance led to the general manager being replaced. Previous literature on board work shows that it is quite a common practice in board work to replace the one that is responsible for the organisational performance (Brennan 2006).

With time there were some changes in the expectations gap. From the perspective of the board, the performance gap was closed by the appointment of the new general manager and the action he took, and they started to perceive Robotdalen as performing well. This resulted in the board's expectation changing such that Robotdalen should not only perform in line with the instructions and the hosting university, but also in line with the board-approved KPIs. The main KPIs were two broad measurements of new products and companies and suggested by the general manager. The KPIs could be argued as a way for the new general manager and his team to be proactive and to manage the expectations gap regarding the lack of perceived performance that the board had expressed. The new KPIs have so far pleased both the financiers and the board and at this stage they are satisfied with the perceived 


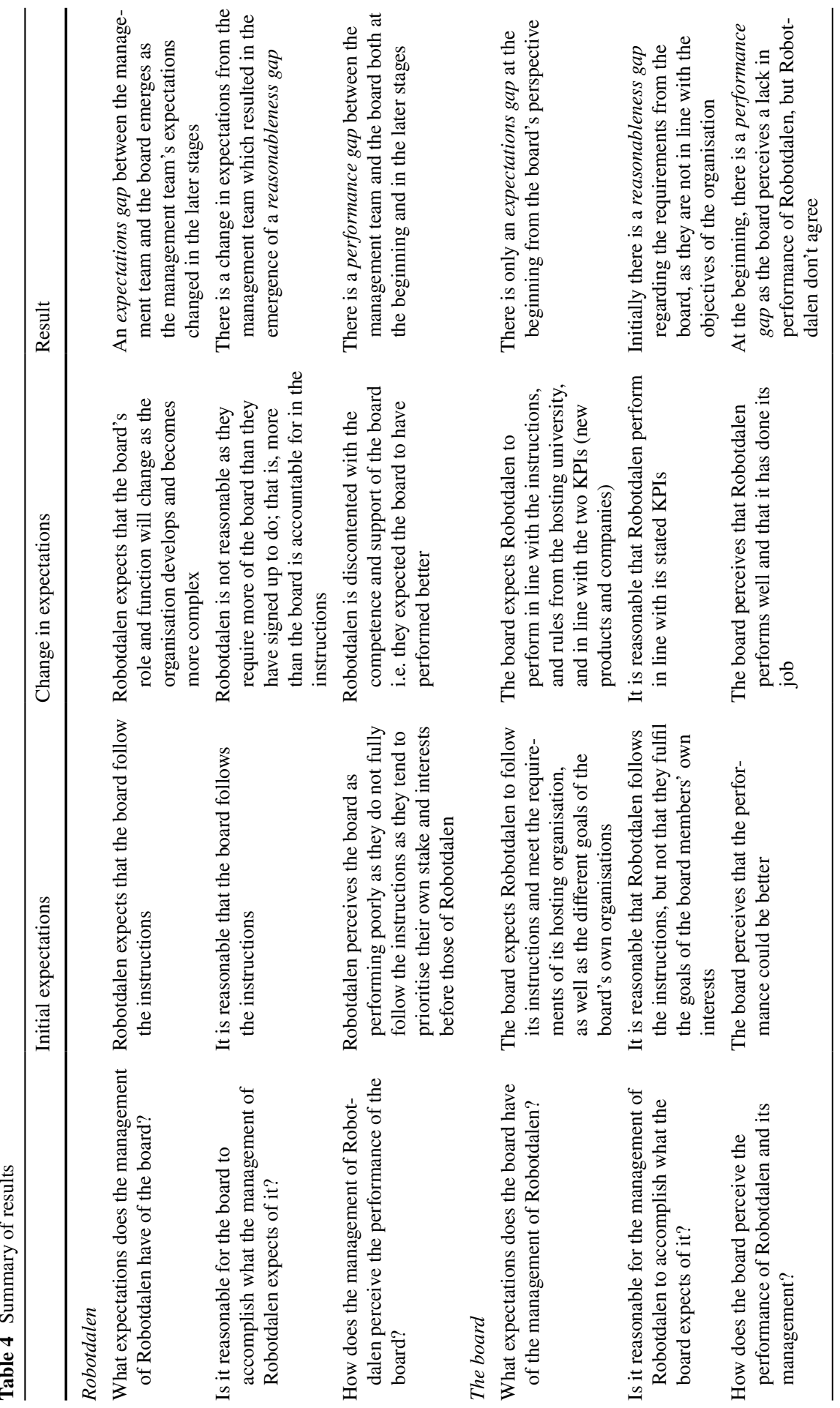


performance of Robotdalen as their expectations are met (cf. Nooteboom et al. 1997; Hooghiemstra and van Manen 2004).

In line with Brennan (2006), it is possible to state that when the board becomes content with the performance, it tends to step back and put its trust in the organisation and the board's tasks of monitoring decreases. However, this is something that the management team of Robotdalen were not pleased with as they instead wanted the board to step up and be more engaged in their work by taking on more of a service role (cf. Cornforth 2003, 2004; Brennan 2006; Minichilli et al. 2009) that could provide new funding and be of help in formulating a new strategic direction. These changes in expectations were among other things a result of the external evaluation that was made in 2010, but also because of the increased pressure from VINNOVA to become self-sufficient. In other words, there is still an expectations gap, but the underlying issue leading to the gap has changed. Moreover, the board stated that they understood that the management team of Robotdalen wanted more help but argued that this was not part of what they had signed up to do and they expected to follow the instructions, which could be considered reasonable. In other words, there is a change in expectations which resulted in the emergence of a new reasonableness gap. This follows the ideas of Cornforth (2012), who argued that an organisation and its board are interdependent with other stakeholders, and therefore do not work in isolation.

This time the expectations gap resulted in the instructions and the board composition being renewed. As the organisation changed and the requirements from external stakeholders changed, so too did the expectations of the management team on the board. This meant that the board's composition, which was built on representativeness rather than competence (cf. Cornforth 2003), resulted in decreased trust and increased expectations from Robotdalen towards the board. Consequently, one could argue that this led to a renewal of the board. This suggests that it is not only important to consider the expectations of the board, but also the expectations of the governed organisation and its management team. In other words, identifying an expectations gap could also lead to the board being replaced or renewed, not only the CEO, as previous research has suggested (cf. Brennan 2006).

\section{Contributions and further research}

With this paper we have contributed a more nuanced theoretical understanding of how governance function is co-produced and the importance of understanding expectation gaps to further understand the dynamics of public sector board work. As stated in the introduction, research on expectations within board work has a great potential for advancing our understanding of the dynamic and interactional aspects that were called for in previous research on public sector governance (see e.g. Cornforth 2003, 2004, 2012; Hinna et al. 2010; Gnan et al. 2013a). This paper is a contribution to this research area. Moreover, our paper meets Cornforth's (2012) call for more processual and qualitative studies of governance in public sector, as this paper contributes with a longitudinal process study of 'what boards do' over time (Michaud 2014, p. 98). 
By summarising the results in Table 4 we enhanced our empirical as well as our theoretical understanding of board work in the public sector. Thus, by analysing the expectation gap through the concepts of a reasonableness gap and a performance gap, we have been able to contribute with a more nuanced picture of the expectations gap in board work, and how expectations change over time. In doing this, we have enhanced not only the understanding of the human side of governance (cf. Huse 2007), but also how governance structures and practices change over time and are influenced by contextual factors. Hence, we have demonstrated how board members, management and different stakeholders all played a role in co-producing governance functions and we can conclude that governance practice entails multiple and multilevel tasks (Höglund et al. 2015) that are affected by the expectations from the board, the management team and other stakeholders.

Drawing upon Cornforth's (2012) broader conceptualisation of public governance, opened up for new subjects to be researched, concerning the relationships between the different parts of the governance system. Thus, we show how funding and financiers' regimes can influence governance functions, structures and practices at the organisational level, and how internal actors such as managers also carry out governance functions (Höglund et al. 2015). For example, in this paper the expectations gap between the board and management, including their largest financier VINNOVA, led to the renewal of the board's role and function. This indicates that an expectations gap might not always be something 'bad' as it also has the potential to renew what was not previously working.

With regard to board dynamics and more precisely the expectations gap in the context of public organisations, our results show that it is of paramount importance to understand stake management (cf. Brennan 2006; Cornforth 2012) and to be able to balance different aspects of accountability, democracy and performance. This is true especially if the organisation is acting in a complex setting of both private and public actors that not only poses monitoring challenges of stakes and interests (cf. Höglund et al. 2015) but also involves differences in strategic goals and values. Public sector actors value democracy and accountability, while private actors tend to value growth and profitability.

In this paper, we have only provided some preliminary insights into how we can understand an expectations gap from a longitudinal approach that highlights the human side of governance and its relational aspects. Therefore, it is important to acknowledge the need for further research in this area. For example, our results demonstrated how funding and financiers' regimes can influence governance functions, structures and practices at the organisational level, and how internal actors such as managers also carry out governance functions. Therefore, exploring how financiers and managements influence the co-production of governance functions would be an area of interest for further research, as well as understanding what other stakeholders might influence governance functions in public sector board work. Moreover, we would also like to encourage further research on board dynamics in public organisations in relation to public governance and accountability (cf. Almquist et al. 2013) and on the impact of expectations in the relationship among a board, the management team and other stakeholders in co-producing different governance functions. 
Open Access This article is distributed under the terms of the Creative Commons Attribution 4.0 International License (http://creativecommons.org/licenses/by/4.0/), which permits unrestricted use, distribution, and reproduction in any medium, provided you give appropriate credit to the original author(s) and the source, provide a link to the Creative Commons license, and indicate if changes were made.

\section{References}

Almquist, R., Grossi, G., van Helden, G. J., \& Reichard, C. (2013). Public sector governance and accountability. Critical Perspectives on Accounting. https://doi.org/10.1016/j.cpa.2012.11.005.

Brennan, N. (2006). Boards of directors and firm performance: Is there an expectations gap? Corporate Governance: An International Review. https://doi.org/10.1111/j.1467-8683.2006.00534.x.

Brown, W. (2005). Exploring the association between board and organizational performance in nonprofit organizations. Nonprofit Management and Leadership. https://doi.org/10.1002/nml.71.

Brown, W. (2007). Board development practices and competent board members: Implications for performance. Nonprofit Management and Leadership. https://doi.org/10.1002/nml.151.

Cepiku, D. (2013). Unraveling the concept of public governance: A literature review of different traditions. In L. Gnan, A. Hinna \& F. Monteduro (Eds.), Conceptualizing and researching governance in public and non-profit organizations. Studies in public and non-profit governance. Bingley: Emerald Books.

Cooke, P., Eickelpasch, A., \& Williams, I. (2010). From low hanging fruit to strategic growth: International evalutation of Robotdalen. Skåne Food Innovation Network and Uppsala BIO. Vinnova Report, VR, 2010, 36.

Cornforth, C. (2003). Summary and conclusions: Contextualising and managing the paradoxes of governance. In C. Cornforth (Ed.), The governance of public and nonprofit organizations: What do boards do? London: Routledge.

Cornforth, C. (2004). The governance of cooperatives and mutual associations: A paradox perspective. Annals of Public and Cooperative Economics. https://doi.org/10.1111/j.1467-8292.2004.00241.x.

Cornforth, C. (2012). Nonprofit governance research: Limitations of the focus on boards and suggestions for new directions. Nonprofit and Voluntary Sector Quarterly. https://doi.org/10.1177/0899764011 427959.

Eisenhardt, K. (1989). Building theories from case study research. Academy of Management Review. https://doi.org/10.5465/AMR.1989.4308385.

Glaser, B. G., \& Strauss, A. L. (1967). The discovery of grounded theory: Strategies for qualitative research. Chicago, IL: Aldine.

Gnan, L., Hinna, A., \& Monteduro, F. (2013a). Introduction. In L. Gnan, A. Hinna, \& F. Monteduro (Eds.), Conceptualizing and researching governance in public and non-profit organizations. Bingley: Emerald Books.

Gnan, L., Hinna, A., \& Scarozza, D. (2013b). Leading organizational changes in public sector building blocks in understanding board behavior. In L. Gnan, A. Hinna, \& F. Monteduro (Eds.), Conceptualizing and researching governance in public and non-profit organizations. Bingley: Emerald Books.

Hinna, A., De Nito, E., \& Mangia, G. (2010). Board of directors within public organisations: A literature review. International Journal of Business Governance and Ethics. https://doi.org/10.1504/IJBGE .2010 .033343 .

Höglund, L., Holmgren Caicedo, M., \& Mårtensson, M. (2015) Managing paradoxes in governance: Tensions in the emergence of a new board. In L. Gnan, A. Hinna \& F. Montedur (Eds.), Contingency, behavioural and evolutionary perspectives on public and nonprofit governance. https://doi. org/10.1108/s2051-663020150000004001.

Höglund, L., \& Linton, G. (2018). Smart specialization in a regional innovation system: A quadruple helix perspective. $R \& D$ Management. https://doi.org/10.1111/radm.12306.

Hooghiemstra, R., \& van Manen, J. (2004). Non-executive directors in the Netherlands: Another expectations gap? Accounting and Business Research. https://doi.org/10.1080/00014788.2004.9729949.

Hung, H. (1998). A typology of the theories of the roles of governing boards. Corporate Governance Scholary Research and Theory Papers. https://doi.org/10.1111/1467-8683.00089.

Huse, M. (2000). Boards of directors in SMEs: A review and research agenda. Entrepreneurship \& Regional Development. https://doi.org/10.1080/08985620050177912. 
Huse, M. (2005). Accountability and creating accountability: A framework for exploring behavioural perspectives of corporate governance. British Journal of Management. https://doi.org/10.111 1/j.1467-8551.2005.00448.x.

Huse, M. (2007). Boards, governance and value creation: The human side of corporate governance. Cambridge: Cambridge University Press.

Huse, M., Minichilli, A., \& Nordqvist, M. (2008). Board leadership and task performance in small firms. In World conference proceedings: 1-2A. Washington: International Council for Small business (ICSB).

Huse, M., \& Rindova, V. P. (2001). Stakeholders' expectations of board roles: The case of subsidiary boards. Journal of Management and Governance. https://doi.org/10.1023/A:1013017909067.

Johnson, J. L., Daily, C. M., \& Ellestrand, A. E. (1996). Boards of directors: A review and research agenda. Journal of Management. https://doi.org/10.1016/S0149-2063(96)90031-8.

McAdam, T. W., \& Gies, D. L. (1985). Managing expectations: What effective board members ought to expect from nonprofit organizations. Nonprofit and Voluntary Sector Quarterly. https://doi. org/10.1177/089976408501400409.

Michaud, V. (2014). Mediating the paradoxes of organizational governance through numbers. Organization Studies. https://doi.org/10.1177/0170840613495335.

Minichilli, A., \& Hansen, C. (2007). The board advisory tasks in small firms and the event of crises. Journal of Management Governance. https://doi.org/10.1007/s10997-007-9014-9.

Minichilli, A., Zattoni, A., \& Zona, F. (2009). Making boards effective: An empirical examination of board task performance. British Journal of Management. https://doi.org/10.111 1/j.1467-8551.2008.00591.x.

Nooteboom, B., Berger, H., \& Noordenhaven, N. G. (1997). Effects of trust and governance on relational risk. Academy of Management Journal, 40(2), 308-338.

OECD. (2012). The robotics innovation challenge. Working Party on the Information Economy, Committee for Information, Computer and Communications Policy, Directorate for Science, Technology and Industry, DSTI/ICCP/IE (2012) 6.

Porter, B. (1993). An empirical study of the audit expectation-performance gap. Accounting and Business Research. https://doi.org/10.1080/00014788.1993.9729463.

Ragin, C. C., \& Becker, H. S. (1992). What is a case? Exploring the foundations of social inquiry. Cambridge: Cambridge University Press. (9th printing 2005).

Siggelkow, N. (2007). Persuasion with case studies. Academy of Management Journal. https://doi. org/10.5465/AMJ.2007.24160882.

Stake, R. E. (1995). The art of case study research. Thousand Oaks, CA: Sage Publications.

Stake, R. E. (1998). Case studies. In N. K. Denzin \& Y. S. Lincoln (Eds.), Strategies of qualitative inquiry. Thousand Oaks, CA: Sage Publications.

Van de Ven, A. (2007). Engaged scholarship: A guide for organizational and social research. Oxford: Oxford University Press.

Verschuere, B., \& Beddeleem, E. (2013). Organisational governance features, innovation and performance in non-profit organisations: Existing evidence and future research directions. In L. Gnan, A. Hinna \& F. Monteduro (Eds.), Conceptualizing and researching governance in public and nonprofit organizations. Studies in public and non-profit governance. Bingley: Emerald Books.

Wiggins, S., \& Potter, J. (2008). Discursive psychology. In C. Willig \& W. S. Rogers (Eds.), The SAGE handbook of qualitative research in psychology. London: SAGE Publications Inc.

Yar Hamidi, D., \& Gabrielsson, J. (2012). From duality to dynamics: Past, present and future in research on board leadership. In EURAM 12th conference in Rotterdam.

Yin, R. (1994). Case study research: Design and methods. Thousand Oaks, CA: Sage publishing.

Linda Höglund (Ph.D.) is an assistant professor at Mälardalen University School of Business, Society and Engineering (EST) and part of AES (the Academy of Management Accounting and Control in Central Government) at Stockholm University, Stockholm Business School (SBS). Höglund focus here research on areas as strategic entrepreneurship as the process of organizing renewal in established organizations, governance, board-work and strategic management in public sector.

Maria Mårtensson (Ph.D.) is an professor at Linnaeus University, School of Business and Economics, and the scientific leader of AES (the Academy of Management Accounting and Control in Central 
Government) at Stockholm Business School. Mårtensson mainly research and publishing here work within the field of management accounting and control and is a project leader of several research projects that takes place within a public sector context.

Aswo Safari (Ph.D.) is assistant professor at the School of Business, Society and Engineering (EST), Mälardalen University. Safari's research focus on different aspects of trust, consumers' international online behavior and especially consumers interaction with different retailers around the world. Safari is also interested in other aspects of international marketing such as firm's internationalization patterns and the impact of psychic distance on international expansions. 